(7)

\title{
Learning to Teach in Higher Education for Sustainable Professional Development
}

\author{
${ }^{a}$ Bibi Haroon, ${ }^{b}$ N. B. Jumani, ${ }^{c}$ Kehkashan Arouj \\ ${ }^{a}$ PhD Scholar, International Islamic University Islamabad, Pakistan \\ ${ }^{\mathrm{b}}$ Professor of Education, International Islamic University Islamabad, Pakistan \\ ${ }^{c}$ Assistant Professor, International Islamic University Islamabad, Pakistan
}

\begin{tabular}{l}
\hline ARTICLE DETAILS \\
History: \\
Accepted 25 March 2020 \\
Available Online 31 March 2020
\end{tabular}

\section{Keywords:}

Learning to Teach, Professional

Development, Higher Education

JEL Classification:

A20, A22, A29

DOI: $10.47067 /$ reads.v6i1.182

\begin{abstract}
The role of teacher in higher education is very complex. It is recognized that academicians have a greater responsibility to pursue excellence in several directions including leadership, academic management, teaching skills, pursuing scholarships, research and knowledge exchange, supervision, and many more to maintain their professional status. Academic practice is a term to encompass all these sides. The main objective of the study is to take the views of the teachers about the participation in different learning opportunities and to see their effect for sustainable professional development of university teachers. All the teachers of public sector universities in Islamabad and Rawalpindi encompass the population of the study. Using purposive sampling technique, data was collected through questionnaires. Chi-square test through SPSS was applied to analyze the data. Data was presented in the form of tables, percentage with graphs and the results were interpreted accordingly.
\end{abstract}

(C) 2020 The authors. Published by SPCRD Global Publishing. This is an open access article under the Creative Commons Attribution-

NonCommercial 4.0

Corresponding author's email address: nb.jumabi@iiu.edu.pk

\section{Introduction}

Standard based education in general and teacher education in particular is part of a global movement for quality assurance. Higher education takes place a prominent position both in national and international level due to the rise of globalization therefore Universities are considered as research platforms and are playing key role into their national development, Communication and digital world. Higher Education institutes are now in more challenging position to accept the revolutionary changes in communication and digital world. So they equip the students with the new challenges of modern world.

Education reforms have already led to a particular growth and competition in higher education sector of Pakistan. Although this is a positive sign and hoped for a developing country like Pakistan that the institutions are meeting the demand of the market for qualified individuals with specialization in different fields as a result of industrial growth in the country.

The study aims to explore the participation of teachers in different learning opportunities and to 
see the participation effect on professional development in higher education. The purpose of the study was that the institutions facilitate to provide different types of learning opportunities, these learning opportunities improve teacher's professional development and the professionally developed teachers can make effective progress in the institution. It is not a comparative study between/among the institutions. But, those teachers considered more effective in teaching practice whose are more professionally developed and experienced. To enhance the quality of higher education by bringing the process of teaching, learning and research in line with international standards (Edu.Policy, 1998-2010).

Therefore, teachers were concerned. Purposive sampling technique was used. Through likert scale "Yes-No," Participation of teachers were asked in different learning activities and to identify their level of effect by providing rich information. For that the given options were (No effect, little effect, Average effect, Greater effect). In order to promote capable and competent university teachers in society, teachers should be given proper training to enhance their competence. In fact, the society needs quality teachers. This requires continuous development of competencies and commitment of teachers to be empowered. The retention of good teacher is a problem throughout the world when compared to other professions they have to educate and mold the entire whole human being. They can change the direction of every thought, feeling and behavior in a right direction. They are the role models for others. So they require more sound professional approach (Sarsani, 2006).

Teaching and learning side by side are useful in bringing to the surface the complex nature of the process of learning to teach not only students, but teachers as well. The teacher's conceptual understanding and cognition of the concept is crucial to student's-learning. The implication for teacher's professional development is to recognize teachers as 'thinking selves' who internalize and utilize knowledge about how students learn in constructing their instructional strategies (Retallick, 2005).

Higher level stress in teachers has been documented by many studies. Sources of teacher stress may include large class size, misbehaving students, heavy paper work, time constraint, lack of educational applies and financial demands which is consideration for educators and for general population as we have facing teachers' shortage in the discipline of science, mathematics and special education. Due to facing stress some teachers can lead to physical and emotional exhaustion, including less job satisfaction, lessen student-teacher rapport and decreased teacher effectiveness in meeting the need of students (kyriacou, 1987).

\section{Literature Review}

The coming generation will be ready to cope with the overwhelming sustainability challenges if education for sustainable development is being learned and taught across educational sectors. The need of capacity to prevent and determine sustainability challenges, on the one hand, and to build and support sustainable development, on the other hand, is at the basis of the sustainability crisis.

A variety of professional development projects are offered to carry and qualify these teachers. The predictable effects of such projects by both the facilitators and the participants are not only concerned to the professional development of individual teachers to get better teacher quality, but also to the enhancement of the quality on the whole.

Both short-term and long-term effects can be considered to be sustainable. So sustainability can be described as the long lasting continuation of achieved benefits and effects of initiative beyond its termination (DEZA, 2005). 
Education sector is expanding very rapidly all over the world in recent years. Globalization and digital revolution has created a demand for new and varied disciplines in education. The cost of providing education has gone up manifold due to better teaching methodologies and learning instruments with rising inflation worldwide (Zaheer \& Rehman, 2010).

\subsection{Learning}

Literally, learning means wisdom, knowledge or scholarship. In psychology 'learning' is defined as modification in behavior through experience. It is the change in the behavior of an individual brought about by his own experiences. Learning is a continuous process that starts from birth to death. An individual learns from his environment throughout his life (Murad, 2010). Learning can be normally improved by the research on educational practices, which is plan for organized improvement and sustainable development in higher education. Discussion of improvement in higher education in Pakistan has become decayed. Up till now, the very definition of education in any form needs an act of transmission of knowledge, usually through an active teaching and learning process. We do not focus innovation in teaching in our higher education and as a consequence, few professors give time to learn new strategies in passing on their message and creating a sense of wonder.

As a rising nation, Pakistan need individuals who can assist it get on nation through high quality education. This is not achievable without the provision of good learning environments and high quality teaching in higher education institutions. Pakistan is in grim need of improvements in both instruction environment and standards of learning; benefits which may be derivative from study on teacher's approaches to teaching at universities (Trigwell and Prosser, 2004).

\subsection{Nature of Learning}

The nature of learning is defined as process of acquisition of new behavior, or strengthening or weakening of old behavior as a result of experience with a view of modifying the behavior. The change of the behavior of an individual occurs because of the experiences and training of day- to- day life. These changes appear in man as habits, aptitudes, skills, knowledge, understanding and insight. Learning also involves a proper adjustment with the environment. However the most important thing in this respect is the change in the character and personality of an individual.

\subsection{Professional Development}

Learning and acquiring teaching skills is a growing trend in educational context, it does not only help them, to develop the required skills and enables them to become competent teachers but it also enables them to generate new theories in the field of education (Donagh, 2012). The research demonstrates the need of increased decentralization and self determination to strengthen the personnel skills elaborate in supervision and stay at local level institutions. Professional supervision and supporting services for teachers is almost in every country (Ali, I998). For the teacher high quality professional development quality opportunities for Professional learning must be organized with a strong base on content that engages teachers to learn, involves collaborations, and must be is sustained over time, and feedback should be collected from colleagues. Such professional development for teachers should be an essential element of the success of the system (DeMonte, 2013).

Within the aspect of participating teachers the several factors are encouraging the impact of professional development programs: If the teachers are engaged in the conception and performance of the program, they can build up an affective relationship towards the program by developing possession of the proposed change (Clarke, 1991; Peter, 1996). They can be empowered to persuade their own development process (Harvey \& Green, 2000). Teachers should be equipped and supported to serve in 
leadership roles (Loucks-Horsley et al., 1996). Teachers can reflect and improve their practice If they understand their role as learners in their own teaching process. Different teachers assume different approaches to teaching. Some researchers have attributed this to constitutional characteristics of the teachers themselves such as diverse lecturing techniques, personality traits or thinking methods.

HEC and other national bodies require generating courses, seminars and training workshops on higher education teaching. Whereas mostly activities at the primary and secondary level, while little is being done at the higher education. Finally, universities and departments must take a serious look at their course evaluation forms and need to modify them to get maximum data that can focus on student learning and teaching performance. With other means, departments should give a sense of the quality of teaching and necessary steps to improve them.

\subsection{Sustainable Professional Development}

Education brings changes in knowledge, attitudes and skills to facilitate a more sustainable development. Education for Sustainable Development is the change in curriculum, learning method, covering economic, social and environmental needs. The sustainable development is fulfilling the needs of the present generation without putting at hazard the ability of generations to come in meeting their own necessities. Teacher professional development is necessary for transforming teaching and learning. It keeps our teachers well aware on advances in education research, efficient practices, and resources. It also trustily affects all aspects of education, for example student outcomes, teacher satisfaction and retention, and learning culture. While some training and workshops can be appealing and inspiring, they don't present the support teachers require to be able to put into practice the new techniques they are exposed to. Continuing teacher professional development has been shown to increase the chances of teachers varying their instructional practices. If done properly it can generate a safe space for teachers to learn new techniques, try them out, reflect on their improvement, ask for suggestion, and get response.

\subsection{Accomplish Needs Assessments}

Each learning situation has its own distinctive challenges and as the education field evolves, even qualified teachers find themselves in need of suggestion. Conducting elevation and surveys frequently will help you better understand your teachers' needs according to the requirements. Teachers should be able to request specific courses or modules on the topics that they are most interested in. This will let you to make demand-driven programming. Like with students, this ownership of their learning is a main component of the teachers' buy-in, serving them stay engaged in their professional development for the long time. The Objectives are to find out the participation of teachers in different learning activities for professional development and to identify the effect of participation in different activities for professional development. The Research Questions are (1) What kinds of learning activities are introduced to university teachers for professional development? (2) What is the participation effect in different activities for professional development?

\section{Research Methodology}

This is a descriptive survey type study. The study is an evaluative and investigative rather than judgmental. This study aims to find out the views of university teachers about the participation in different learning activities and to see the participation effect on the professional development of teachers. All full time teachers of public sector universities in Islamabad and Rawalpindi in Pakistan constitute the population of the study. Purposive sampling technique was used. The questionnaire was used for data collection. The research approach was quantitative in nature but some open-ended questions also included. So mixed method sequential research design was adopted. The researcher 
administered and collected all questionnaires personally.

\section{Analysis}

\subsection{Participation of teachers in different learning activities}

Table 1 Respondents views for the Participation in workshop

\begin{tabular}{|lccccc|}
\hline Options & Observed No & Percent $\%$ & Expected No & df & Chi-Square \\
\hline No responses & 02 & 1.0 & 100.5 & & \\
\hline Yes & 12 & 6.0 & 100.5 & 2 & 323.134 \\
\hline No & 187 & 93.0 & 100.5 & & \\
\hline Total & 201 & 100.0 & & & \\
\hline
\end{tabular}

This table shows that $93.0 \%$ respondents participated in workshops and only $6 \%$ respondents did not participate, while $1 \%$ did not response. From the statistical analysis of the results it is evident that the value of chi-square $\mathrm{x}^{2}=323.134>34.825 \mathrm{a}=0.05$ and $\mathrm{df}=2$. Therefore the result was strongly significant which showed that mostly respondents participated in workshops for professional development.

Table 2 Respondents view for the Participation in Training Course

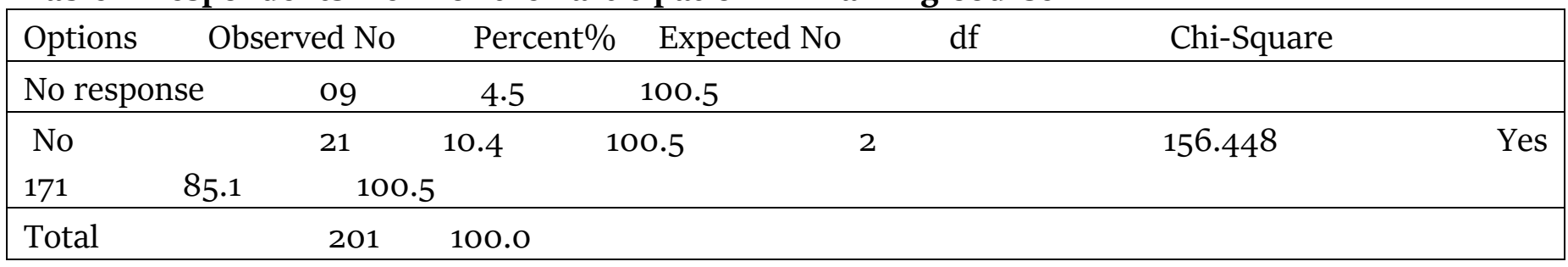

This table shows that $85.1 \%$ respondents were of the view that they participated in training courses and 10.4\% respondents were non-participants. While $4.5 \%$ were not respondents for this learning opportunity of professional development. From the statistical analysis of the results it is evident that the value of chi-square is $\mathrm{x}^{2}=156.448>34.825 \mathrm{a}=0.05$ and $\mathrm{df}=2$. Therefore the result was statistically significant which showed that most of the respondents participated in training courses for professional development.

Table 3 Respondents views of Literature Reading for Professional Development

\begin{tabular}{|cccccc|}
\hline Options & Observed No & Percent $\%$ & Expected No & df & Chi-Square \\
\hline No responses & 04 & 2.0 & 100.5 & & \\
\hline No & 19 & 9.5 & 100.5 & 2 & 277.522 \\
\hline Yes & 178 & 88.6 & 100.5 & & \\
\hline Total & 201 & 100.0 & & & \\
\hline
\end{tabular}

This table shows that $88.6 \%$ respondents were of the view that they had the opportunity for literature reading and they could read different type of literature on professional and educational topics for professional development and 9.5\% respondents did not avail such type of opportunity. While 2.0 $\%$ were the non respondents. From the statistical analysis of the results it is evident that the value of chi-square is $\mathrm{x}^{2}=277.522>34.825 \mathrm{a}=0.05$ and $\mathrm{df}=2$ Therefore the result was significant statistically. 


\begin{tabular}{|lccccc|}
\hline Options & Observed No & Percent $\%$ & Expected No & df & Chi-Square \\
\hline No responses & 06 & 3.0 & 100.5 & & \\
\hline No & 19 & 9.5 & 100.5 & 2 & 267.254 \\
\hline Yes & 176 & 87.6 & 100.5 & & \\
\hline Total & 201 & 100.0 & & & \\
\hline
\end{tabular}

This table shows that $87.6 \%$ respondents were of the views that they often had the opportunity for informal dialogues with colleagues on professional and educational topics. And $9.5 \%$ respondents had not availed such type of opportunity. While 3.0 \% were the non respondents for that. From the statistical analysis of the results it is evident that the value of chi-square is $\mathrm{x}^{2}=267.254>34.825 \mathrm{a}=$ 0.05 and $\mathrm{df}=2$. Therefore the result was significant.

\subsection{Effect of Teachers' Participation in Different Learning Activities}

This table demonstrates that calculated value of chi-square was found 106.935 which were greater than the tabulated value, which were 34.8258 at 0.05 level of significance. It points out that the responses of participants differed significantly. Majority of the respondents (86\%) agreed that the workshops were very effective for their professional development.

Table 5 Effect of Participation in Workshops

\begin{tabular}{|lccclc|}
\hline Options & Observed No & Percent $\%$ & Expected No & df & Chi-Square \\
\hline No responses & 27 & 13.4 & 40.2 & & \\
\hline No effect & 01 & 0.5 & 40.2 & 4 & 106.935 \\
\hline Little effect & 25 & 12.4 & 40.2 & & \\
\hline Average effect & 80 & 39.8 & 40.2 & & \\
\hline Greater effect & 68 & 33.8 & 40.2 & & \\
\hline Total & 201 & 100.0 & & & \\
\hline
\end{tabular}

Table 6 Effect of Informal Dialogues with Colleagues

\begin{tabular}{|lccccccc|}
\hline Options & Observed No & Percent $\%$ & Expected No & df & Chi-Square & & \\
\hline No responses & 29 & 14.4 & 40.2 & & & little & effect \\
\hline $\begin{array}{l}\text { No effect } \\
16\end{array}$ & 05 & 2.5 & 40.2 & 4 & 124.050 & \\
\hline Average effect & 59 & 29.4 & 40.2 & & & \\
\hline Greater effect & 92 & 45.8 & 40.2 & & & \\
\hline Total & 201 & 100.0 & & & & \\
\hline
\end{tabular}

This table shows that calculated value of chi-square was found 124.050 which were greater than the tabulated value, that 34.8258 at 0.05 level of significance it points out that the responses of participants differed significantly. Majority of the respondents (83.2\%) agreed that the informal dialogues with colleagues were proved highly effective for the professional development of university teacher.

Table 7 Effect of Training Courses on Educational Topics

\begin{tabular}{|c|c|c|c|c|}
\hline Options & Observed No & Percent $\%$ & Expected No df & Chi-Square \\
\hline No responses & 52 & 25.9 & 40.2 & \\
\hline
\end{tabular}


Review of Economics and Development Studies, Vol. 6 (1) 2020,

\begin{tabular}{|lccccc|}
\hline No effect & 12 & 6.0 & 40.2 & 4 & 46.438 \\
\hline Little effect23 & \multicolumn{5}{c|}{40.2} \\
\hline Average effect & 63 & 11.4 & 41.3 & 40.2 & \\
\hline Greater effect & 51 & 25.4 & 40.2 \\
\hline Total & 201 & 100.0 & & \\
\hline
\end{tabular}

Table 7 depicts that calculated value of chi-square was found 46.438 which was greater than the tabulated value, which was 34.8258 at 0.05 level of significance and points out that the responses of participants differed significantly as little effect $11.4 \%$, average effect $31.3 \%$ and greater effect was $25.4 \%$. Thus majority of the respondents of $(68.1 \%)$ totally agreed that the training courses on educational topics were effective for them.

Table 8 Effect of Professional Literature Reading

\begin{tabular}{|lccccc|}
\hline Options & Observed No & Percent $\%$ & Expected No df & Chi-Square \\
\hline No responses & 36 & 17.9 & 40.2 & & \\
\hline No effect & 07 & 3.5 & 40.2 & 4 & 131.463 \\
\hline Little effect & 10 & 5.0 & 40.2 & & \\
\hline Average effect & 52 & 25.9 & 40.2 & & \\
\hline Greater effect & 96 & 47.8 & 40.2 & & \\
\hline Total & 201 & 100.0 & & & \\
\hline
\end{tabular}

Table 8 depicts that calculated value of chi-square was found 131.463 which was greater than the tabulated value, which was 34.8258 at 0.05 percent significant. It points out that the responses of participants differed significantly. Majority respondents $(78.7 \%)$ were totally revealed that professional literature reading was effective for their career development.

\section{Findings}

- $\quad$ Findings were shown that 93\% university teachers participated in workshops,

- It was found that $85 \%$ teachers were participated in different professional trainings.

- $\quad$ The result was shown as $88 \%$ teachers were benefits of professional literature reading,

- $\quad$ The study finding that $87 \%$ teachers participated in informal dialogue.

- Greater effect were found in workshops -------- $86 \%$

- $\quad$ Effect of Informal dialogues -------------------- 83.2\%

- Effect of training courses ----------------------- $68.16 \%$

- Effect of literature reading ----------------------- 78.7\%

Good effect were shown which is above $70 \%$ in

- Literature reading,

- Teaching skills,

- Conferences,

- Individual research and

- Teaching method.

\section{Conclusion}

Teachers' participation were asked in different learning activities by likert scale "Yes, No" and to identify the level of effect of their participation by providing rich information. For that the given 
options were (No effect, little effect, Average effect, Greater effect). Findings show that the participation in professional development activities was on the progressive side. Participation indicated in workshops (93.0\%), training courses $(85.1 \%)$ and informal dialogues with colleagues $(87.6 \%)$ were increasing to enhance their performance. The current study also concluded that greater effect of participation in workshops, informal dialogues, training courses in higher education. Good effect on teaching methods, individual research and teaching skills, participation in seminars and conferences etc. both National and International level increase the professional development of teachers.

- Participation in professional development activities were the progressive.

- Workshops were in excellence position with best effect. Training courses and informal dialogues were the best.

- Participation in educational seminar and conferences, individual research, use latest

Research based teaching contents, teaching method accordance with the teaching Community and teaching skills accordance with the changing environmental demands.

This shows better effect. Findings shown that the participation in professional development activities were in Progress Participation indicated in workshops, training courses and informal dialogues With colleagues were increasing. So participation in professional activities is essential for Continuous professional development that affect the career of teachers.

\section{Recommendations}

- More participation in collaborative research may be encouraged.

- Network participation for sharing in groups may be increased.

- Innovations in teaching method and evaluation mean latest development in pedagogy and andragogy.

\section{References}

A.Murad, (2010). A Comprehensive Study of Education. University Publishers Peshawar.

Ali, M. A. (1998). Supervision for Teacher Development: A Proposal for Pakistan. UNESCO International Institute for Educational Planning.

Aldridge, S. and Rowely, J. (1998), "Measuring customer satisfaction in higher education”, Quality Assurance in Education, 6(4), 197-204.

Butt, B. Z., \& Rehman, K. (2010). A study examining the students satisfaction in higher education. Procedia-Social and Behavioral Sciences, 2(2), 5446-5450.

Campbell, T. A., and Campbell, D. E. (1997), "Faculty/student mentor program: effects on performance and retention", Research in Higher Education, 38(6), 727-742.

Clarke, D. M. (1991). The role of staff development programs in facilitating professional growth. Madison, WI: University of Wisconsin

Donagh, C. \& more (2012). Enhancing Practice through Classroom Research a Teacher's Guide To Professional Development. Routledge Taylor \& Francis Group London \& NewYork.P1.

Direktion fur Entwicklungshilfe und Zusammenarbeit / DEZA. (2005). Glossar deutsch. Bern: DEZA.

How to Run Sustainable Teacher Professional Development Programs Al Qasimi Foundation June 29, 2017

Harvey, L., \& Green, D. (2000). Qualität definieren [Defining quality]. Zeitschrift für Pädagogik, Beiheft, 41, 17-37.

IMechE (2013), How is a product of The Professional Development Partnership from MechE

IMAREST, IET, IOP AND Rees. Content is copyright of the Professional development Partnership. C 2013. 
Iqbal, T., Saeed, A. \& Akhter, M. (2019). A Study of University Teachers' Approaches to Teaching at Undergraduate Level in Punjab, Pakistan: Bulletin of Education and Research April 2019, Vol. 41, No. 1 pp. 147

Kyriacou, c.(1987). Teacher stress and burnout: An international review. Educational Research, 29, 146152

Loucks-Horsley, S., Stiles, K., \& Hewson, P. (1996). Principles of effective professional Development for mathematics and science education: A synthesis of standards. NISE Brief, 1(1), 1-6.

Peter, A. (1996). Aktion und Reflexion - Lehrerfortbildung aus international vergleichender Perspektive [Action and reflection - teacher education from an international comparative perspective]. Weinheim, Germany: Deutscher Studien Verlag.

Retallick, J. (2005). Transforming Schools in Pakistan. Oxford University Press. P-17

Redman, E., Wiek, A., Redman, A. (2018). Continuing Professional Development in Sustainability Education for K-12 Teachers: Principles, Program, Applications, Outlook. First Published July 11, 2018 Research Article. https://doi.org/10.1177/2455133318777182

Sarsani, M. R. (2006). Quality Improvement in Teacher Education. New Delhi: Sarup \& Sons.

Trigwell, K., \& Prosser, M. (2004). Development and use of the approaches to teaching inventory, Educational Psychology Review, 16, 409-424. Available at <www.educationcounts.govt.nz/goto/BES>

Zaheer\&Rehman, (2010). A study examining the students satisfaction in higher education. Procedia Social and Behavioral Sciences 2 (2010) 5446-5450.

Zaman, M.H. (2012).Innovations in Higher Education Teaching. Published: June 4, 2012

Zehetmeier, S., Andreitz, I., Erlacher, W., \& Rauch, F. (2015). Researching the impact of teacher Professional development programmes based on action research, Constructivism and systems theory. 